Article

\title{
Comparison of Environmental Impact of Three Different Slab Systems for Life Cycle Assessment of a Commercial Building in South Korea
}

\author{
Inkwan Paik ${ }^{1}$ and Seunguk $\mathrm{Na}^{2, * \mathbb{i}}$ \\ 1 Super-Tall Building Global R\&BD Centre, The 2nd Engineering hall, 152 Jukjeon-ro, Yongin-si, \\ Gyeonggi-do 16890, Korea; ikpaik@dankook.ac.kr \\ 2 Department of Architectural Engineering, College of Architecture, Dankook University, 152 Jukjeon-ro, \\ Yongin-si, Gyeonggi-do 16890, Korea \\ * Correspondence: drseunguk@dankook.ac.kr; Tel.: +82-31-8005-3747
}

Received: 11 July 2020; Accepted: 13 October 2020; Published: 17 October 2020

\begin{abstract}
The environmental impacts of the construction stage should be considered since a large amount of building materials are used to construct a building at this stage. Studies on the improvement of construction techniques or the application of newly developed construction methods for reducing the environmental impacts are relatively scant compared to other topics of studies. This study aimed to assess and compare the environmental impacts of the ordinary solid slab, the flat plate slab and the voided slab system during the construction phase. A process-based quantitative model was adopted to evaluate the environmental impacts and the comparative results were analysed to demonstrate the significant characteristics of the environmental impacts of the construction of slab in a building. The assessment results show that the environmental impacts from the ordinary solid slab are the highest and the voided slab system is the lowest among three slab systems. As the slab system of the studied building was replaced, it was shown that the environmental impact indicators showed the decreased tendency. Based on the results of environmental impact reduction from the ordinary solid slab, the flat plate slab and the voided slab system, the voided slab system would have the least environmental impact in all indicators.
\end{abstract}

Keywords: environmental performance; life cycle assessment; life cycle inventory; ordinary solid slab; flat plate slab; the voided slab system

\section{Introduction}

Recent years have seen growing interest in the reduction in environmental burden, in order to achieve sustainable development throughout all industries [1-4]. Roh et al. [1] analysed the embodied environmental impacts of apartment buildings by major construction tasks to identify the major source of environmental impact. Moreover, Gorobets [2] suggested solutions to achieve sustainable development, such as technological aspects as well as political approaches. As a means of mitigating environmental impact, most industries have enacted strict environmental regulations, and also spontaneously researched various approaches to reduce their environmental load. Likewise, the construction industry is no longer an exception to such alleviation of environmental problems. It is reported that annually the construction industry consumes more than $40 \%$ of the total global energy demand. In addition, this industry produces approximately $33 \%$ of the total carbon dioxide emissions per annum [5-8]. Various studies have been carried out to minimise the environmental loads in the construction industry, which not only consumes enormous energy but also emits greenhouse gases, including carbon dioxide [8-11]. Basbagll et al. [8] suggested that the early design stage would be one of the critical 
stages for reduction in embodied environmental impact through utilisation of Building Information Modelling (BIM). In addition, Na and Paik [9] examined the greenhouse gas emissions of alternative structural systems with a combination of construction costs. Kumar et al. [10] evaluated the relationship between the energy consumption and the greenhouse gas emissions over the variables of life cycle in Canadian cases.

The construction industry has unique features that need to be considered when the reduction in environmental impact is addressed. Constructing a building consists of many phases from building material production, their transportation, and utilising equipment and machinery during construction work. Moreover, the whole life cycle of a building has more than 30 years for the operation and maintenance phase, compared to other products or services [11-14]. Throughout the long life cycle of a building, the building not only consumes a large amount of energy, but also releases a considerable amount of Greenhouse Gases (GHGs) during the operation and maintenance phase. Due to the long life cycle of a building, the majority of studies regarding environmental impact have focused on the operation and maintenance stage [15-17].

Sandanayake et al. [5] indicate that the energy consumed in this operation and maintenance stage phase is about $70 \%$ of the total energy consumption during the overall life of a building. Due to the huge energy consumption in this stage, there are a number of newly developed technologies and efforts to decrease the energy consumption and emissions of greenhouse gases during operation and maintenance. For example, zero-energy housing would make it possible to reduce a significant amount of energy consumption of residential buildings from heating, ventilation, and air-conditioning [18-20]. Moreover, highly advanced computing technologies, and newly emerging techniques, such as Artificial Intelligence (AI), big data, and machine learning, could make it possible to accurately predict the amount of energy consumption as well as GHG emissions during this period, as a means of precautional approaches for mitigating environmental impact. Edwards et al. [21] compared different machine learning techniques to predict accurate energy consumption for residential homes in the USA. Likewise, Oh and Na [22] adopted Building Information Modelling (BIM) for a tool to predict the life cycle carbon dioxide emissions during the design stage in South Korea. Ren et al. [23] suggested a prediction model for total energy consumption and associated GHG emissions, in order to achieve cost-effective energy saving in Australian residential buildings. As a result of such technological development and prediction techniques, the environmental impacts associated with energy consumption and GHG emissions from the operation and maintenance stage of a building have tended to decrease.

Although the construction phase, which consists of several phases, is relatively shorter than the operation and maintenance phase, its environmental impact should be considered, since large amounts of building materials are used to construct a building in this stage. Since a number of studies have maintained that one of the main sources of environmental impact during the construction stage is the manufacture of building materials [4,5,14,24-27], the reduction in environmental impact from building materials would be the most effective approach to mitigate the environmental impact and greenhouse gases emissions. Goverse et al. [28], for instance, pointed out that replacing traditional building materials, such as concrete, rebars, or bricks, by low embodied carbon ones would lower the environmental impact by almost $50 \%$. Moreover, the application of high-strength materials, such as high-strength reinforcing bars, and reinforced concrete might achieve lower environmental impact, since the amount of utilised building materials is reduced [25,29-31]. With the use of high-strength materials, applying recycled materials and by-products from the demolition stage is also suggested as an effective approach to alleviate the environmental burdens from construction work [32-35]. Moreover, the optimal structural design of a building would be an important stage to determine the construction methods and building materials that lower the environmental impacts from the study of Han et al. [24].

As discussed above, the mitigation of environmental impacts that occur from the construction phase is mainly focused on the replacement of low environmental impact materials, the optimal structural design of a building, and increasing the use of recycled materials or by-products. However, studies on the improvement of construction techniques or the application of newly developed 
construction methods for reducing the environmental impact are relatively scant, compared to other research topics. In particular, slabs are one of the significant elements for a building; they provide flat surfaces for occupants, as well as transferring various loads through beams, girders, and columns to the ground. While the main focus of research on slabs is to verify the structural performance, including stability against flexural, shear, or seismic loads, and structural design optimisation [36-39], there are few studies on the evaluation of the environmental impact of different slab systems $[3,40,41]$. For example, Ferreiro-Cabello et al. [42] evaluated the carbon dioxide emissions from slabs of different thickness and suggested optimal structural design for environmental performance and structural reliability. In order to fill the gap in research, the purpose of this study is to assess and compare the environmental impact of the Ordinary Solid Slab (OSS), the Flat Plate Slab (FPS), and the Voided Slab System (VDS) during the construction phase. The assessed environmental impact indicators in this research cover Global Warming Potential (GWP), Acidification Potential (AP), Eutrophication Potential (EP), Ozone Layer Depletion Potential (ODP), Photochemical Ozone Creation Potential (POCP), and Abiotic Depletion Potential (ADP). In this study, the construction phase includes the manufacture of building materials, transportation of the building materials to the construction site, and the utilisation of construction equipment.

\section{Research Methodology}

In this study, Life Cycle Assessment (LCA) methodology was applied, in order to evaluate the environmental impact of the OSS, the FPS, and the VDS. According to ISO 14044 [43], LCA is a practical tool to assess and evaluate the environmental impacts of a product, process, or service throughout its life cycle. Three methods are mainly adopted, namely process-based analysis, economic input-output analysis, and a hybrid approach that would be utilised for environmental performance evaluation over the life cycle [44-47].

Process-based analysis is a bottom-up approach to evaluate environmental performance in consideration of all the processes and activities that are involved in producing a product or service that is in compliance with ISO 14044 [48] and ISO 21930 [49]. This method would identify all materials and energy used during the production to evaluate the environmental impacts. In addition, a process-based method would require high quality data to produce a more conclusive assessment of environmental impacts when economic input-output data are unavailable.

Economic input-output analysis is a top-down method that considers both direct and indirect environmental impacts during the life cycle of a product or service. This approach evaluates the direct environmental impacts of a project or service, as well as the indirect ones associated with the supply chain of the product or service. Nässén et al. [50] applied an input-output analysis for the analysis of both direct and indirect energy use and carbon emissions during the production phase of buildings. Their study pointed out the difference between top-down and bottom-up analysis of the input-output approach, which showed difference in transport and the service sector of the construction of buildings. For economic input-output analysis, it is time consuming to accumulate extensive data from all of the relevant areas to enhance the accuracy of the results. This approach is prevalent in studies from the USA and Japan because of the accuracy of the data [11,14,45].

Hybrid analysis is a combination of above-mentioned approaches to calculate the environmental impacts. It would make it possible to enhance the accuracy of the environmental performance evaluation complementary to insufficient data from either process-based or economic input-output analysis. There are two types of hybrid analysis: process-based hybrid analysis, and economic input-output-based hybrid analysis, depending upon which method is applied, and the basis $[44,46,51,52]$. Process-based hybrid analysis assesses the environmental performance based on the process-based analysis procedure, and input-output analysis would supplement insufficient data [35,44,46,51]. Likewise, economic input-output hybrid analysis would perform LCA by mainly applying economic input-output analysis, while process-based analysis would fill the lack of data. 
In this research, process-based analysis of LCA is applied to assess and evaluate the environmental impacts of three slab systems during the construction phase for an apartment building in South Korea. The procedure of this study was composed of goal and scope definition, life cycle inventory analysis, and impact assessment in accordance with ISO 14044 (see Figure 1) [48].

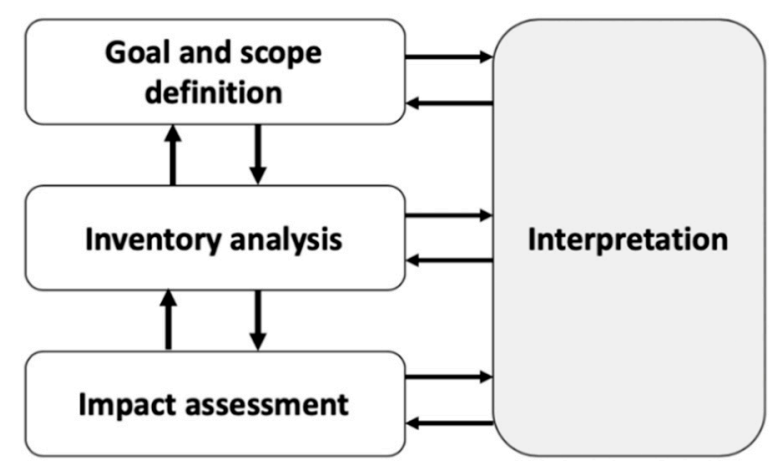

Figure 1. Life cycle assessment.

\subsection{Goal and Scope Definition}

The goal of this study is to assess the environmental impacts of three different slab systems, which are the OSS, the FPS and the VDS for apartment buildings in South Korea. Slabs are one of the significant structural members for buildings. They not only transfer various loads through beams, girders, and columns to the ground, but also provide flat surfaces for building occupants. Since constructing high-rise commercial or residential buildings is common in urban areas around the world, the role of slabs has grown to facilitate more storeys. When the construction of slabs is carried out during the construction phase, a vast amount of concrete and reinforcing bars is required. Conventionally, slabs would require a large number of beams and girders to secure the structural stability of buildings or facilities. While the conventional method of constructing slabs would require vast amounts of building materials, such as concrete and reinforcing bars, the self-weight of the building itself would be increased as a result of the input amount of building materials. It is reported that there are several disadvantages in terms of the conventional construction method of slabs, such as extended construction period and costs, as apply to high-rise building construction. In order to sort out such difficulties resulting from application of the conventional slab system, new methods for slab systems have been introduced and applied to high-rise buildings. The FPS and the VDS are alternative approaches for slab systems, which make it possible to reduce the amount of building materials as well as the construction period and costs, compared to the ordinary solid slabs.

In this study, the system boundary for assessing the environmental impact is the construction phase (i.e., cradle to pre-operation) for the three slab systems. This includes embodied emissions from the production of building materials, emissions due to transportation of the manufactured materials to the construction site, and emissions from the utilisation of machines and equipment (see Figure 2). Six environmental impact indicators, which are Global Warming Potential (GWP), Acidification Potential (AP), Eutrophication Potential (EP), Ozone Layer Depletion Potential (ODP), Photochemical Ozone Creation Potential (POCP), and Abiotic Depletion Potential (ADP), were selected for assessing the environmental impacts of three slab systems. GWP refers to the average temperature rise level of the surface of the Earth, which is a parameter of the climate changes causing the ecosystem changes in soil and water. AP indicates the fate and deposition caused by acidifying substances, such as $\mathrm{SO}_{2}, \mathrm{NH}_{3}$, and $\mathrm{NO}_{\mathrm{x}}$ on soil, water, organisms, ecosystems, and materials. This is mainly affected by the circulation of pollutants and would threaten the survival of living organisms on the Earth. EP is the polluted state of aquatic ecosystem, such as algal growth and red tides, since the biomass in the water is grown by over-fertilisation of water and soil. ODP is a measure of the density decrease in the ozone layer that is located in the stratosphere as a result of trichlorofluoromethane (R-11 or 
CFC-11). This would be harmful effects on human skin through the increased exposure to Ultraviolet Ray (UV) radiation. POCP refers to the formation of ozone with photochemical oxidation of Volatile Organic Compounds (VOCs) and Carbon Monoxide (CO) and would affect damage to ecosystems and human health. ADP is the decreasing of natural resource availability, including fossil fuel resources and minerals. This means the amount of non-renewable resources on the earth is being reduced.

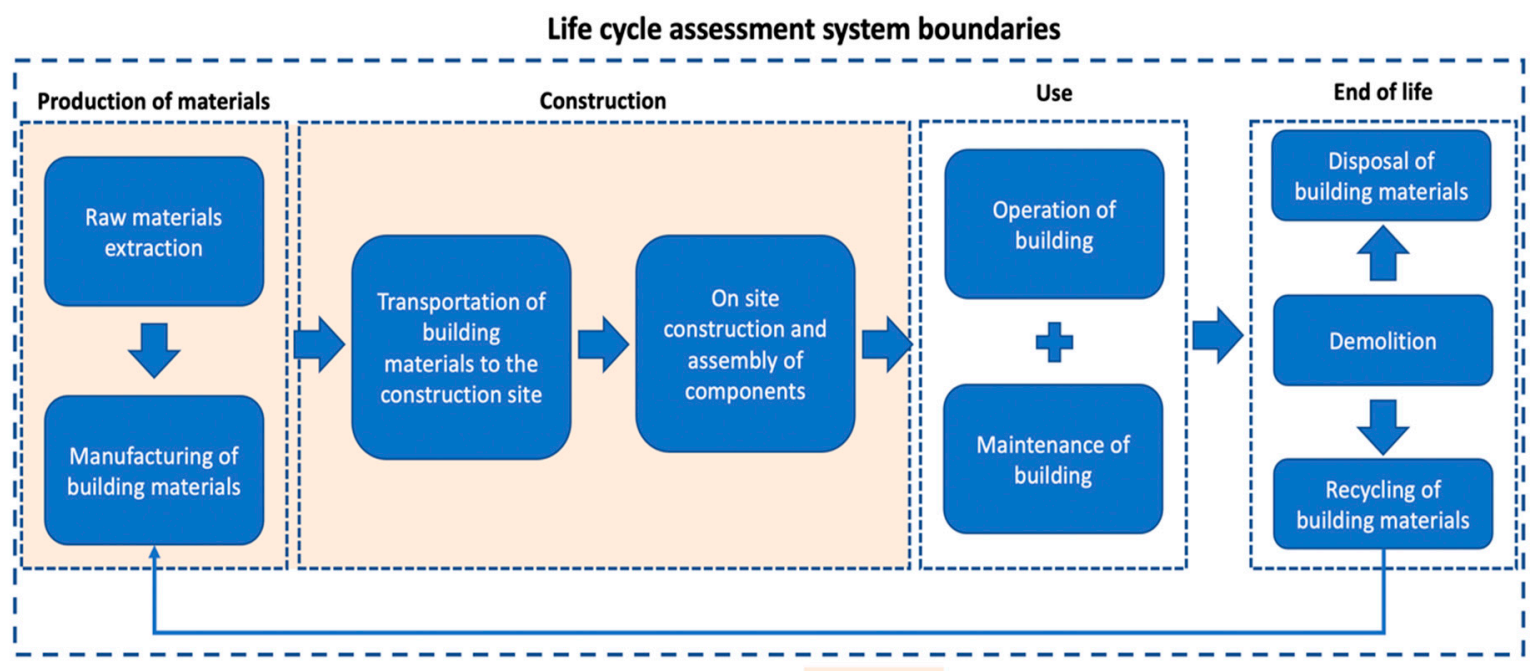

: System boundary of the study (Cradle to pre-operation)

Figure 2. System boundary of this study.

\subsection{Life Cycle Inventory Analysis}

Based on the system boundary, the life cycle inventory analysis was carried out to compare the environmental impacts of three slab systems. In this study, the production stage evaluates the embodied environmental impacts of the building materials required for the OSS, the FPS, and the VDS. The evaluated building materials were ready-mixed concrete, reinforcing bars, steel decking, and void formers for permanent materials, and plywood forms for temporary material. The quantities of building materials were computed from the actual input data from the bill of quantities. Likewise, the transportation stage was the required transportation methods for each material of the flat plate slab and the voided slab system (see Table 1). The types of transportation methods of this study were ready-mixed concrete trucks for conveying ready-mixed concrete, 4.5-ton lorries for plywood forms, anchoring materials and void formers, and 11.5-ton lorries for reinforcing bars and steel decking. The equipment and machines used during the construction stage were a mobile crane for loading reinforcing bars, forms, anchoring materials, steel decking and void formers, vibrators for concrete pouring and concrete pump cars for movement of concrete from the ground level to upper levels of the studied building.

Table 1. Transportation methods of building materials.

\begin{tabular}{cccc}
\hline Building Materials & Transportation Methods & Distance $\mathbf{( k m )}$ & Reference \\
\hline Ready-mixed concrete & Concrete mixer $\left(5 \mathrm{~m}^{3}\right)$ & 25 & \\
Reinforcing bars & 11-ton lorry & 63 & Korea Life Cycle Inventory \\
Steel decking & 11-ton lorry & 318 & Database (KLCI DB) [53] \\
Plywood forms & 4.5-ton lorry & 72 & \\
Void formers & 4.5-ton lorry & 210 & \\
\hline
\end{tabular}

Table 2 shows the Life Cycle Inventory Databases of this study for evaluating the environmental impacts of the flat plate slab and the voided slab system. The life cycle inventory databases in this study were mainly adopted from the National Life Cycle Inventory Database of South Korea by the 
Ministry of Environment [53]. Additionally, the Ökobaudat standardised database from the Federal Ministry of the Interior, Building and Community for Germany as indicated in Table 2 was applied as a means of complementing the insufficient database of the Korean Life Cycle Inventory Database (LCI DB) [54].

Table 2. Life cycle inventory database.

\begin{tabular}{ccc}
\hline Process & Materials & Reference \\
\hline & Ready-mixed concrete & Korea Life Cycle Inventory DB \\
Production of materials & Reinforcing bars & Korea Life Cycle Inventory DB \\
& Forms (plywood) & Korea Life Cycle Inventory DB \\
& Steel decking & Ökobaudat database \\
& Void formers (expanded polystyrene) & Ökobaudat database \\
Transportation & Anchoring materials & Korea Life Cycle Inventory DB \\
& Concrete mixer $\left(5 \mathrm{~m}^{3}\right)$ & Korea Life Cycle Inventory DB \\
& 4.5-ton lorry & Korea Life Cycle Inventory DB \\
Construction & 11-ton lorry & Korea Life Cycle Inventory DB \\
& Vibrator & Korea Life Cycle Inventory DB \\
& Mobile crane & Korea Life Cycle Inventory DB \\
& Concrete pump car & Korea Life Cycle Inventory DB \\
\hline
\end{tabular}

\subsection{Impact Assessment}

The following equations are applied to quantitative evaluation of the environmental impacts from the flat plate slab and the voided slab system. The total environmental impacts from six categories would be measured from Equation (1) below:

$$
I_{\text {Total }}=I_{P}+I_{T}+I_{C}
$$

where $I_{\text {Total }}$ is the total environmental impact of each of the categories, which are the production of building materials $\left(I_{P}\right)$, transportation of building materials $\left(I_{T}\right)$, and use of construction equipment and machines on site $\left(I_{C}\right)$. In this study, each impact category is evaluated from Equation (2) as below:

$$
I_{n}=\sum_{i=1}^{6} E I F_{c a t, i} \times Q_{s}
$$

where In is the environmental impact from each stage, $\mathrm{i}$ is each category of the environmental impact

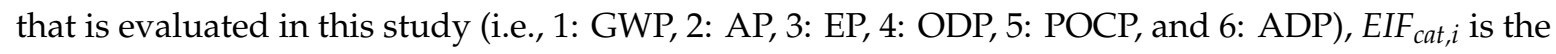
emission facto of each category $i$, and $Q_{s}$ is the amount of building materials, vehicles, or machinery of this study. Table 3 indicates the environmental impact factors of each source in this study.

\subsection{Case Description}

The analysed case of this study is a commercial building located in Seoul, South Korea, of which the construction began in August 2014, and was completed in April 2016. The floor area of the typical floor is $2427.57 \mathrm{~m}^{2}$, and the total floor area is $48,551.4 \mathrm{~m}^{2}$. Figure 3 shows the plan of a typical floor. The thickness of a slab was designed to $300 \mathrm{~mm}$, and beams and girders were varied, depending upon the type of slab system applied in this study. The rebars for reinforcement of the concrete that were applied were 12.70, 15.90, and $19.10 \mathrm{~mm}$, with a yield stress of $400 \mathrm{MPa}$. The rebars for upper and lower reinforcement were of diameter 12.70 and $15.90 \mathrm{~mm}$, and 15.90 and $19.10 \mathrm{~mm}$, respectively. 
Table 3. Factors of environmental impacts.

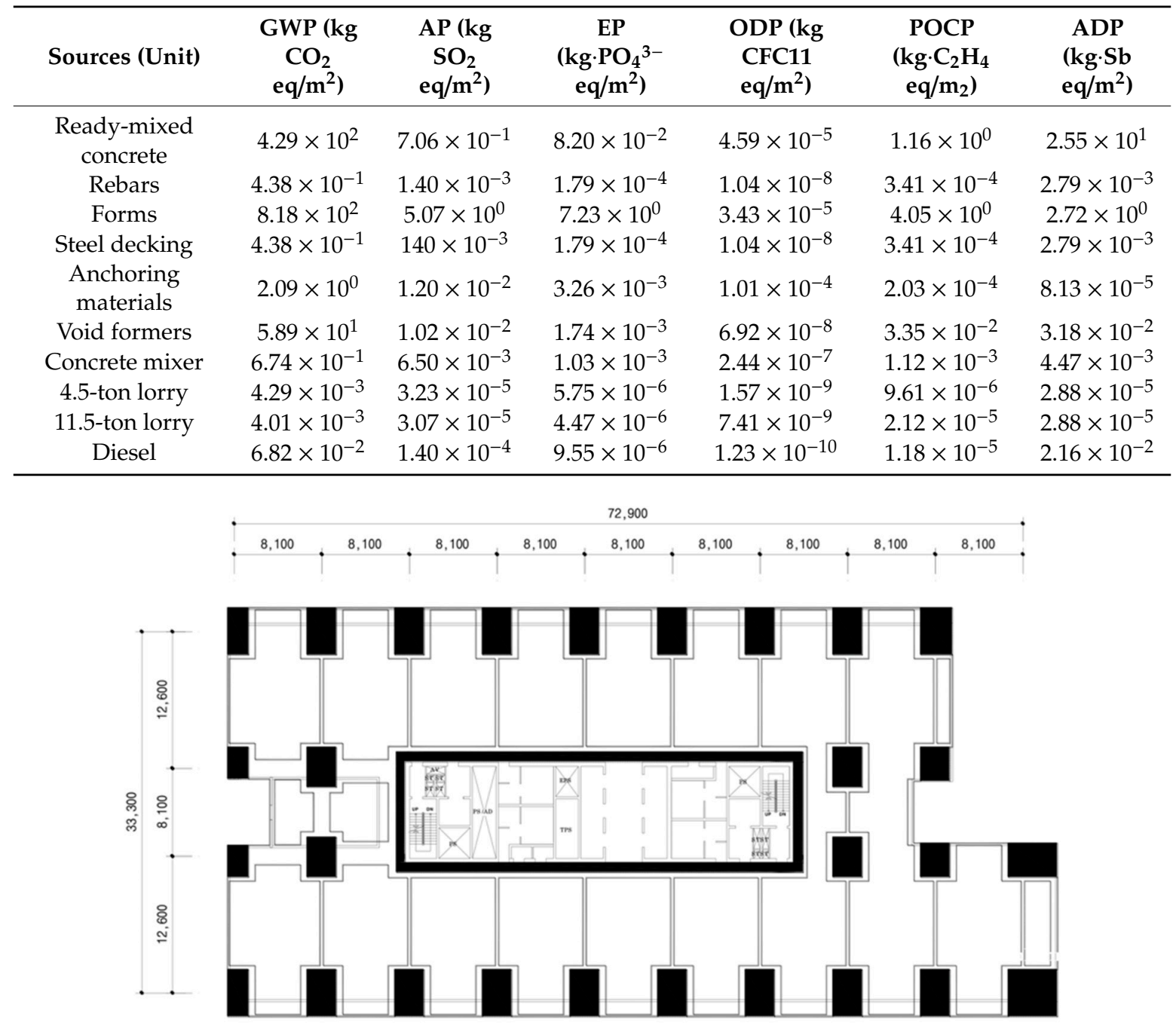

Figure 3. Typical floor plan of the studied building.

The apartment building of this study was initially designed with the OSS, which is one of the commonly applied slab systems in South Korea, in accordance with the Structural Concrete Design Code and Commentary by the Korea Concrete Institute [55] and ACI 318-05 [56]. During the value analysis stage before the construction documentation stage, the structural design team suggested alternative slab systems, which would make it possible to achieve both economic and structural aspects. In this process, the cost-effectiveness and maximisation of space utilisation were the most significant factors to choose a substitution of the OSS. The FPS and the VDS were proposed as possible changes to the OSS (see Figure 4).

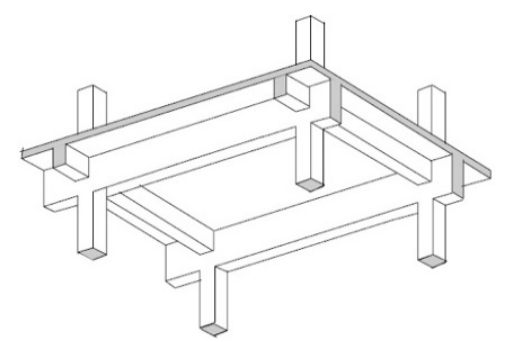

(a) The ordinary solid slab

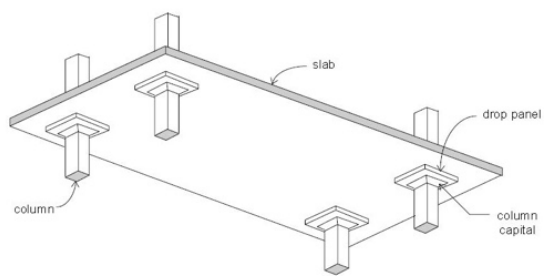

(b) The flat plate slab system

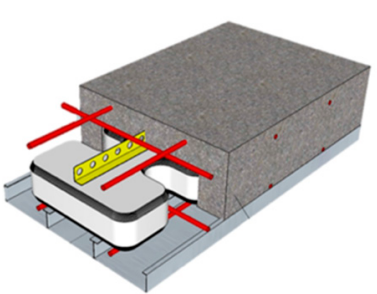

(c) The voided slab system

Figure 4. Schematics of the slab systems. 
The FPS is one of the reinforced concrete slab systems that directly connect slabs to columns, without the use of beams and girders. Since this slab system does not use beams and girders, there are several advantages, such as simple formworks during the construction phase, and enhanced serviceability for occupants during the operation phase. Likewise, the VDS is a newly developed slab system that reduces the self-weight of the slab, and this would make it possible to extend the span between columns. According to Hong et al. [57], the nominal strength of the ORC and the VDS showed $20.3 \mathrm{kN}$ and $75.7 \mathrm{kN}$, respectively. This result indicated that the structural performance of the VDS would be better than the ORC and potential replacement of the ORC to the VDS. The anchoring mechanism of the voided slab system overcomes the problems of the existing hollow core slab systems, which are the precision of positioning void formers and excessive application of anchoring devices (see Figure 4).

\section{Results and Discussion}

\subsection{Analysis of the Total Environmental Impacts}

Table 4 shows the results of the environmental impacts of each environmental impact indicator for the OSS, the FPS and the VDS during the construction phase (i.e., manufacturing building materials, transportation of building materials, and construction machinery). The result shows that the environmental impacts during the construction phase from OSS are the highest for all environmental impact indicators, while the total environmental impacts of the VDS are the lowest environmental impacts among the three slab systems for all environmental impact indicators.

Table 4. Total environmental impacts of flat plate slab.

\begin{tabular}{|c|c|c|c|c|c|c|c|c|c|c|c|c|}
\hline \multirow{2}{*}{$\begin{array}{c}\text { Environmental } \\
\text { Impact } \\
\text { Indicators } \\
\text { (Unit) }\end{array}$} & \multicolumn{3}{|c|}{$\begin{array}{c}\text { Manufacturing Building } \\
\text { Materials }\end{array}$} & \multicolumn{3}{|c|}{$\begin{array}{c}\text { Transportation of } \\
\text { Building Materials }\end{array}$} & \multicolumn{3}{|c|}{ Construction Machinery } & \multicolumn{3}{|c|}{ Total } \\
\hline & OSS & EPC & VDS & OsS & FPS & VDS & & FPS & VDS & OsS & FPS & VDS \\
\hline $\begin{array}{l}\mathrm{GWP}\left(\mathrm{kg} \mathrm{CO} \mathrm{CO}_{2}\right. \\
\left.\mathrm{eq} / \mathrm{m}^{2}\right)\end{array}$ & $\begin{array}{c}1.72 \times \\
10^{2}\end{array}$ & & & & & & & & & & & $\begin{array}{c}1.99 \times \\
10^{2}\end{array}$ \\
\hline $\begin{array}{r}\mathrm{AP}(\mathrm{kg} \\
\mathrm{eq} / \mathrm{n}\end{array}$ & $\begin{array}{c}4.83 \times \\
10^{-1}\end{array}$ & & & & & & & & & & & \\
\hline $\begin{array}{c}\mathrm{EP}\left(\mathrm{kg} \mathrm{PO}_{4}{ }^{3-}\right. \\
\left.\mathrm{eq} / \mathrm{m}^{2}\right)\end{array}$ & $\begin{array}{c}3.79 \times \\
10^{-1}\end{array}$ & $\begin{array}{c}3.74 \times \\
10^{-1}\end{array}$ & $\begin{array}{c}2.84 \times \\
10^{-1}\end{array}$ & $\begin{array}{c}8.78 \times \\
10^{-2}\end{array}$ & $\begin{array}{c}9.11 \times \\
10^{-2}\end{array}$ & & $\begin{array}{c}2.92 \times \\
10^{-2}\end{array}$ & $\begin{array}{c}2.77 \times \\
10^{-2}\end{array}$ & $\begin{array}{r}2.0 \\
10\end{array}$ & $\begin{array}{c}4.96 \times \\
10^{-1}\end{array}$ & $\begin{array}{c}3.84 \times \\
10^{-1}\end{array}$ & $\begin{array}{c}2.95 \times \\
10^{-1}\end{array}$ \\
\hline $\begin{array}{c}\text { ODP }(\mathrm{kg} \\
\text { CFC11 eq/m²) }\end{array}$ & $\begin{array}{l}6.28 \times \\
10^{-4}\end{array}$ & $\begin{array}{l}6.16 \times \\
10^{-4}\end{array}$ & $\begin{array}{r}5.10 \\
10^{-}\end{array}$ & & $\begin{array}{l}1.69 \times \\
10^{-4}\end{array}$ & & $\begin{array}{l}5.18 \times \\
10^{-5}\end{array}$ & $\begin{array}{l}4.83 \times \\
10^{-5}\end{array}$ & $\begin{array}{l}3.88 \times \\
10^{-5}\end{array}$ & $\begin{array}{c}8.55 \times \\
10^{-4}\end{array}$ & $\begin{array}{l}6.16 \times \\
10^{-4}\end{array}$ & $\begin{array}{c}5.10 \times \\
10^{-4}\end{array}$ \\
\hline $\begin{array}{c}\mathrm{POCP}(\mathrm{kg} \\
\left.\mathrm{C}_{2} \mathrm{H}_{4} \mathrm{eq} / \mathrm{m}^{2}\right)\end{array}$ & $\begin{array}{c}3.54 \times \\
10^{-1}\end{array}$ & $\begin{array}{c}2.91 \times \\
10^{-1}\end{array}$ & $\begin{array}{c}2.87 \times \\
10^{-1}\end{array}$ & $\begin{array}{c}9.53 \times \\
10^{-2}\end{array}$ & $\begin{array}{c}6.99 \times \\
10^{-2}\end{array}$ & $\begin{array}{c}6.60 \times \\
10^{-2}\end{array}$ & $\begin{array}{c}2.83 \times \\
10^{-2}\end{array}$ & $\begin{array}{c}2.31 \times \\
10^{-2}\end{array}$ & $\begin{array}{c}2.24 \times \\
10^{-2}\end{array}$ & $\begin{array}{c}4.78 \times \\
10^{-1}\end{array}$ & $\begin{array}{c}3.04 \times \\
10^{-1}\end{array}$ & $\begin{array}{c}2.97 \times \\
10^{-1}\end{array}$ \\
\hline $\begin{array}{l}\mathrm{ADP}(\mathrm{kg} \mathrm{Sb} \\
\left.\mathrm{eq} / \mathrm{m}^{2}\right)\end{array}$ & $\begin{array}{c}9.24 \times \\
10^{-1}\end{array}$ & $\begin{array}{c}9.05 \times \\
10^{-1}\end{array}$ & $\begin{array}{c}6.89 \times \\
10^{-1}\end{array}$ & & $\begin{array}{c}1.72 \times \\
10^{-1}\end{array}$ & & & & & $\begin{array}{c}1.18 \times \\
10^{1}\end{array}$ & $\begin{array}{c}1.16 \times \\
10^{1}\end{array}$ & $\begin{array}{c}8.66 \times \\
10^{-1}\end{array}$ \\
\hline
\end{tabular}

According to Table 4, the stage of manufacturing building materials demonstrates the greatest environmental impact factors in all indicators for all three slab systems of this study. The transportation of building materials from manufacturers to the construction site is the second greatest environmental impact source in all cases. The usage of construction machinery and equipment have the lowest value, compared to other stages, for the OSS, the FPS and the VDS. For the GWP in OSS, the FPS, and the VDS, the effects of the manufacture of building materials, transportation of building materials, and usage of construction machinery were approximately $69 \%, 23 \%$, and $8 \%$, respectively. Moreover, the results of other environmental impact indicators (i.e., Acidification Potential, Eutrophication Potential, Ozone Layer Depletion Potential, Photochemical Ozone Creation Potential, and Abiotic Depletion Potential) show similar results to the GWP, which for manufacturing building materials, transportation of building materials, and usage of construction machinery are about $75 \%, 18 \%$, and $7 \%$, respectively (see Figure 5). 


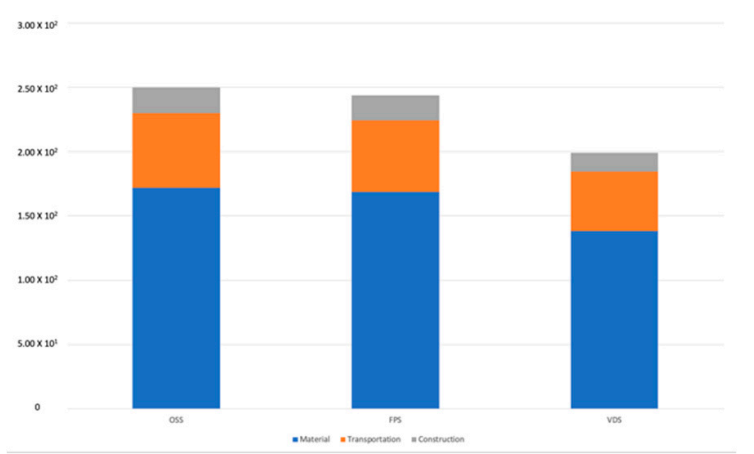

(a) Global Warming Potential $\left(\mathrm{kg} \mathrm{CO} 2 \mathrm{eq} / \mathrm{m}^{2}\right)$

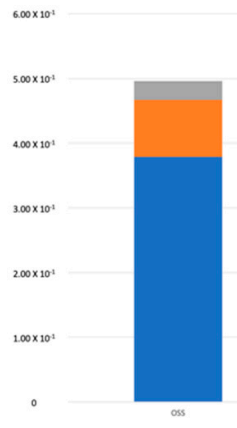

(c) Eutrophication Potential $\left(\mathrm{kg} \mathrm{PO}_{4}{ }^{3-} \mathrm{eq} / \mathrm{m}^{2}\right)$

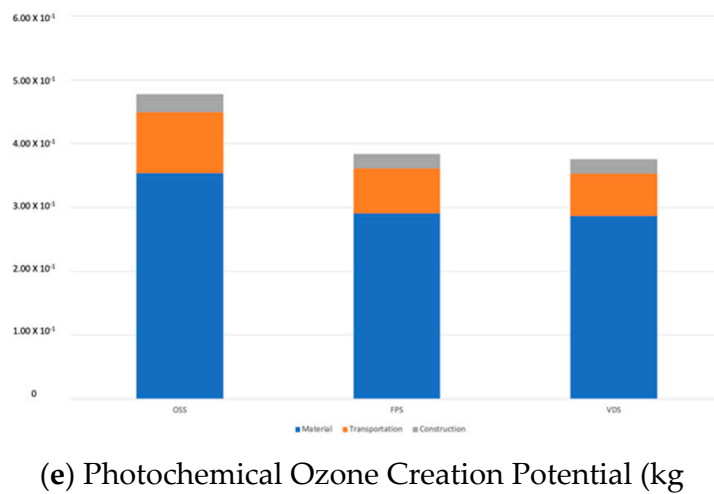

(e) Photochemical Ozone Creation Potential $(\mathrm{kg}$

CFC11 eq $/ \mathrm{m}^{2}$ )

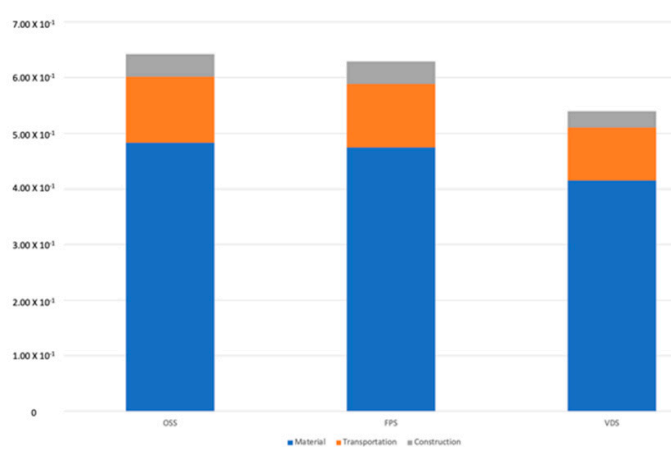

(b) Acidification Potential ( $\left.\mathrm{kg} \mathrm{SO} 2 \mathrm{eq} / \mathrm{m}^{2}\right)$

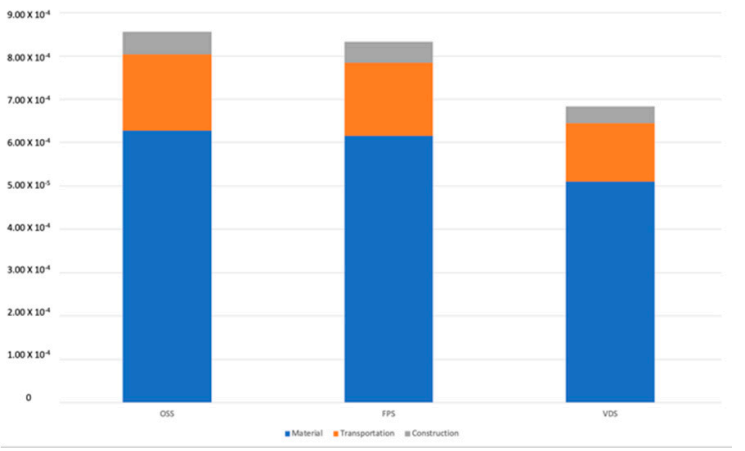

(d) Ozone Depletion Potential (kg CFC11 eq/m²)

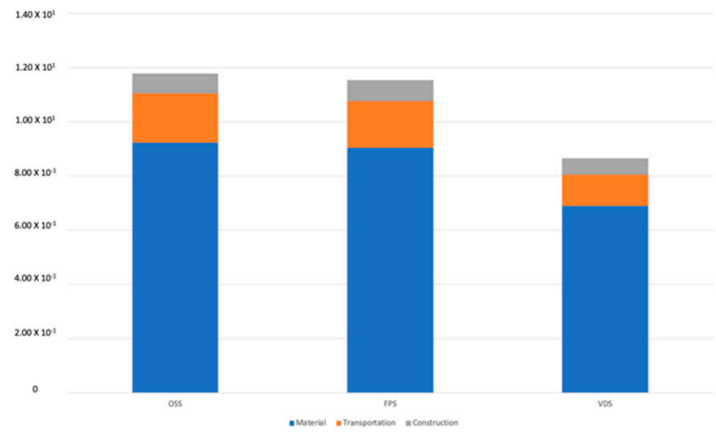

(f) Abiotic Depletion Potential (kg Sb eq/m²)

Figure 5. Reduction in environmental impacts.

Table 5 summarises the reduction in environmental impacts by the application of alternative slab systems compared to the OSS. It was found that all the environmental impact indicators showed decreasing tendency as the selection of the slab system of the building changed from the OSS to the FPS to the VDS. In this research, the application of the FPS and the VDS would lower the environmental impacts from all the indicators, compared to the OSS. In particular, replacing the OSS by the VDS shows the highest reduction ratio of all the environmental impact indicators.

In addition, the reduction ratio between the FPS and the VDS indicates the second largest value in all environmental impact indicators. While the change of slab system from the OSS to the FPS would lead to lower environmental impact, the reduction ratio of this variation is relatively smaller than for the other cases of this study (i.e., substituting the ordinary reinforced concrete slab by the flat plate slab or the voided slab system).

Although the environmental impacts from the OSS to the FPS show a decreased tendency, the ratio is the smallest, as shown in column 3 in Table 5. Based on the results of the environmental impact reduction from the three slab systems, the VDS would incur the least environmental impacts in all indicators and is one of the effective replacements of slab systems to mitigate the environmental burdens. 
Table 5. Reduction in environmental impact indicators.

\begin{tabular}{|c|c|c|c|c|c|c|}
\hline $\begin{array}{l}\text { Environmental Impact } \\
\text { Indicators (Unit) }\end{array}$ & FPS-OSS & $\begin{array}{l}\text { Reduction } \\
\text { Ratio }\end{array}$ & VDS-OSS & $\begin{array}{l}\text { Reduction } \\
\text { Ratio }\end{array}$ & VDS-FPS & $\begin{array}{l}\text { Reduction } \\
\text { Ratio }\end{array}$ \\
\hline $\operatorname{GWP}\left(\mathrm{kg} \cdot \mathrm{CO}_{2} \cdot \mathrm{eq} / \mathrm{m}^{2}\right)$ & $\begin{array}{c}6.22 \times \\
10^{0}\end{array}$ & 2.55 & $\begin{array}{l}5.09 \times \\
10^{1}\end{array}$ & 25.57 & $\begin{array}{c}4.47 \times \\
10^{1}\end{array}$ & 22.45 \\
\hline $\mathrm{AP}\left(\mathrm{kg} \mathrm{SO} \mathrm{eq}_{2} / \mathrm{m}^{2}\right)$ & $\begin{array}{c}1.38 \times \\
10^{-2}\end{array}$ & 2.20 & $\begin{array}{c}1.03 \times \\
10^{-1}\end{array}$ & 19.12 & $\begin{array}{c}8.93 \times \\
10^{-2}\end{array}$ & 16.56 \\
\hline $\mathrm{EP}\left(\mathrm{kg} \cdot \mathrm{PO}_{4}{ }^{3-} \cdot \mathrm{eq} / \mathrm{m}^{2}\right)$ & $\begin{array}{c}3.30 \times \\
10^{-3}\end{array}$ & 0.67 & $\begin{array}{c}1.21 \times \\
10^{-1}\end{array}$ & 32.42 & $\begin{array}{c}1.18 \times \\
10^{-1}\end{array}$ & 31.53 \\
\hline ODP (kg.CFC11 eq/m²) & $\begin{array}{l}2.13 \times \\
10^{-5}\end{array}$ & 2.55 & $\begin{array}{c}1.71 \times \\
10^{-4}\end{array}$ & 25.16 & $\begin{array}{c}1.51 \times \\
10^{-4}\end{array}$ & 22.04 \\
\hline POCP $\left(\mathrm{kg} \cdot \mathrm{CFC} 11 \mathrm{eq} / \mathrm{m}^{2}\right)$ & $\begin{array}{c}9.40 \times \\
10^{-2}\end{array}$ & 24.7 & $\begin{array}{c}1.03 \times \\
10^{-1}\end{array}$ & 27.32 & $\begin{array}{c}8.58 \times \\
10^{-3}\end{array}$ & 2.28 \\
\hline $\mathrm{ADP}\left(\mathrm{kg} \cdot \mathrm{Sb} \cdot \mathrm{eq} / \mathrm{m}^{2}\right)$ & $\begin{array}{c}2.51 \times \\
10^{-2}\end{array}$ & 2.17 & $\begin{array}{c}3.14 \times \\
10^{-1}\end{array}$ & 36.24 & $\begin{array}{c}2.89 \times \\
10^{-1}\end{array}$ & 33.34 \\
\hline
\end{tabular}

\subsection{The Environmental Impact Analysis of Each Phase}

Figure 5 shows the proportion and variation of environmental impacts from each stage during the construction of slab systems. This study shows the similar contribution of environmental impact from all of the indicators for the OSS, the FPS, and the VDS. Materials production is the highest environmental impact contributor in all indicators during the construction of the three slab systems. There are a number of studies to assess carbon dioxide emissions in terms of strengthening the building materials, utilisation of by-products and recycled materials during the construction stage $[24,25,28-31]$. Although few studies have evaluated the environmental indicators of building materials, this study assessed GWP, AP, EP, ODP, POCP and ADP of three different slab systems. The results of this study would be expected to be helpful in evaluating GWP, AP, EP, ODP, POCP and ADP for other construction methods and building materials. Transporting building materials to the construction site is the second largest environmental impact source amongst the three slab systems. In this study, transporting the building materials was influenced by the distance and the fuel efficiency of the transporting method. The three environmental impacts from transporting building materials show similar results, which are that the ordinary reinforced concrete is the highest, while the VDS is the lowest. In particular, the environmental impacts for transportation stage are lower than other systems, even though it was noticeable that the VDS required more building materials than other slab systems. The reason that the environmental impacts of transporting building materials are lower is that the number of required vehicles was small since the weight of steel decking and void formers is lighter than other building materials in this study. Although the construction period is relatively longer than the other stages, the reason for the low environmental impact in all three cases might seem to be closely related to the unique characteristics of the construction and building industry. It is commonly recognised that one of the distinctive features of modern industries is automation. However, the construction and building industry is comparatively behind such trend. In this study, in all three cases, the consumption of fuel from construction machinery was low, and the environmental impact was considered to be lower than for the other stages, since the number of utilised items of construction equipment was small and limited. In the case of the VDS, the environmental impact from utilising the construction equipment was lower than that of the other two slab systems, although two more building materials were applied to construct the VDS.

\subsection{The Environmental Impact Analysis of Building Materials}

Tables 6 and 7 summarise the environmental impact assessment results from each building material for the three different slab systems. In this study, the major building materials were considered to assess the environmental impact during the construction of slab systems. The major building materials were ready-mixed concrete, rebars, forms for the OSS and the FPS. In the case of the VDS, 
three additional building materials, namely, anchoring steel materials, steel decking, and void formers, were applied to construct the VDS, compared to the OSS and the FPS.

Table 6. The environmental impact of building materials.

\begin{tabular}{|c|c|c|c|c|c|c|c|c|c|}
\hline & \multicolumn{3}{|c|}{$\mathrm{GWP}\left(\mathrm{kg} \mathrm{CO} \mathrm{Cl}_{2} \mathrm{eq} \mathrm{m}^{2}\right)$} & \multicolumn{3}{|c|}{$\mathrm{AP}\left(\mathrm{kg} \mathrm{SO} \mathrm{eq}_{2} / \mathrm{m}^{2}\right)$} & \multicolumn{3}{|c|}{$\mathrm{EP}\left(\mathrm{kg} \mathrm{PO}_{4}{ }^{3-} \mathrm{eq} / \mathrm{m}^{2}\right)$} \\
\hline & OsS & FPS & VDS & OsS & FPS & VDS & OSS & FPS & VDS \\
\hline $\begin{array}{l}\text { Ready-mixed } \\
\text { concrete }\end{array}$ & $\begin{array}{l}1.26 \times \\
10^{2}\end{array}$ & $\begin{array}{l}1.18 \times \\
10^{2}\end{array}$ & $\begin{array}{c}8.07 \times \\
10^{1}\end{array}$ & $\begin{array}{c}2.08 \times \\
10^{-1}\end{array}$ & $\begin{array}{c}1.93 \times \\
10^{-1}\end{array}$ & $\begin{array}{c}1.33 \times \\
10^{-1}\end{array}$ & $\begin{array}{c}2.41 \times \\
10^{-2}\end{array}$ & $\begin{array}{c}2.25 \times \\
10^{-2}\end{array}$ & $\begin{array}{c}1.54 \times \\
10^{-2}\end{array}$ \\
\hline Rebars & $\begin{array}{c}1.28 \times \\
10^{1}\end{array}$ & $\begin{array}{c}1.19 \times \\
10^{1}\end{array}$ & $\begin{array}{c}1.09 \times \\
10^{1}\end{array}$ & $\begin{array}{c}4.08 \times \\
10^{-2}\end{array}$ & $\begin{array}{c}3.79 \times \\
10^{-2}\end{array}$ & $\begin{array}{c}3.49 \times \\
10^{-2}\end{array}$ & $\begin{array}{c}5.22 \times \\
10^{-3}\end{array}$ & $\begin{array}{l}4.85 \times \\
10^{-3}\end{array}$ & $\begin{array}{c}4.46 \times \\
10^{-3}\end{array}$ \\
\hline Forms & $\begin{array}{c}4.17 \times \\
10^{1}\end{array}$ & $\begin{array}{c}3.93 \times \\
10^{1}\end{array}$ & $\begin{array}{c}2.78 \times \\
10^{1}\end{array}$ & $\begin{array}{c}2.59 \times \\
10^{-1}\end{array}$ & $\begin{array}{c}2.43 \times \\
10^{-1}\end{array}$ & $\begin{array}{c}1.72 \times \\
10^{-1}\end{array}$ & $\begin{array}{c}3.69 \times \\
10^{-1}\end{array}$ & $\begin{array}{c}3.47 \times \\
10^{-1}\end{array}$ & $\begin{array}{c}2.46 \times \\
10^{-1}\end{array}$ \\
\hline $\begin{array}{c}\text { Steel } \\
\text { materials }\end{array}$ & N.A. & N.A. & $\begin{array}{c}565 \times \\
10^{-1}\end{array}$ & N.A. & N.A. & $\begin{array}{c}1.80 \times \\
10^{-3}\end{array}$ & N.A. & N.A. & $\begin{array}{c}2.31 \times \\
10^{-4}\end{array}$ \\
\hline Steel decking & N.A. & N.A. & $\begin{array}{c}1.03 \times \\
10^{1}\end{array}$ & N.A. & N.A. & $\begin{array}{c}5.93 \times \\
10^{-2}\end{array}$ & N.A. & N.A. & $\begin{array}{l}1.61 \times \\
10^{-2}\end{array}$ \\
\hline Void formers & N.A. & N.A. & $\begin{array}{c}8.03 \times \\
10^{0}\end{array}$ & N.A. & N.A. & $\begin{array}{c}1.39 \times \\
10^{-2}\end{array}$ & N.A. & N.A. & $\begin{array}{c}2.73 \times \\
10^{-3}\end{array}$ \\
\hline
\end{tabular}

Table 7. The environmental impacts of building materials (continued).

\begin{tabular}{|c|c|c|c|c|c|c|c|c|c|}
\hline & \multicolumn{3}{|c|}{ ODP (kg CFC11 eq/m $\left.\mathrm{m}^{2}\right)$} & \multicolumn{3}{|c|}{ POCP $\left(\mathrm{kg} \mathrm{C}_{2} \mathrm{H}_{4} \mathrm{eq} / \mathrm{m}^{2}\right)$} & \multicolumn{3}{|c|}{$\operatorname{ADP}\left(\mathrm{kg} \mathrm{Sb} \mathrm{eq} / \mathrm{m}^{2}\right)$} \\
\hline & OSS & FPS & VDS & OSS & FPS & VDS & OSS & FPS & VDS \\
\hline $\begin{array}{l}\text { Ready-mixed } \\
\text { concrete }\end{array}$ & $\begin{array}{l}1.35 \times \\
10^{-5}\end{array}$ & $\begin{array}{c}1.26 \times \\
10^{-5}\end{array}$ & $\begin{array}{c}8.63 \times \\
10^{-6}\end{array}$ & $\begin{array}{c}3.41 \times \\
10^{-1}\end{array}$ & $\begin{array}{c}5.98 \times \\
10^{-2}\end{array}$ & $\begin{array}{l}2.1 \times \\
10^{-1}\end{array}$ & $\begin{array}{c}7.50 \times \\
10^{-1}\end{array}$ & $\begin{array}{c}6.99 \times \\
10^{-1}\end{array}$ & $\begin{array}{c}4.79 \times \\
10^{-1}\end{array}$ \\
\hline Rebars & $\begin{array}{c}3.03 \times \\
10^{-7}\end{array}$ & $\begin{array}{l}2.82 \times \\
10^{-7}\end{array}$ & $\begin{array}{c}2.59 \times \\
10^{-7}\end{array}$ & $\begin{array}{c}9.94 \times \\
10^{-3}\end{array}$ & $\begin{array}{c}2.30 \times \\
10^{-1}\end{array}$ & $\begin{array}{c}8.50 \times \\
10^{-3}\end{array}$ & $\begin{array}{c}8.13 \times \\
10^{-2}\end{array}$ & $\begin{array}{c}7.56 \times \\
10^{-2}\end{array}$ & $\begin{array}{l}6.96 \times \\
10^{-2}\end{array}$ \\
\hline Forms & $\begin{array}{c}1.75 \times \\
10^{-6}\end{array}$ & $\begin{array}{c}1.65 \times \\
10^{-6}\end{array}$ & $\begin{array}{l}1.17 \times \\
10^{-6}\end{array}$ & $\begin{array}{c}2.07 \times \\
10^{-2}\end{array}$ & $\begin{array}{c}6.61 \times \\
10^{-4}\end{array}$ & $\begin{array}{c}1.38 \times \\
10^{-2}\end{array}$ & $\begin{array}{c}1.39 \times \\
10^{-1}\end{array}$ & $\begin{array}{c}1.31 \times \\
10^{-1}\end{array}$ & $\begin{array}{c}9.25 \times \\
10^{-2}\end{array}$ \\
\hline $\begin{array}{c}\text { Steel } \\
\text { materials }\end{array}$ & N.A. & N.A. & $\begin{array}{l}1.34 \times \\
10^{-8}\end{array}$ & N.A. & N.A. & $\begin{array}{c}4.40 \times \\
10^{-4}\end{array}$ & N.A. & N.A. & $\begin{array}{c}3.60 \times \\
10^{-3}\end{array}$ \\
\hline Steel decking & N.A. & N.A. & $\begin{array}{c}5.00 \times \\
10^{-4}\end{array}$ & N.A. & N.A. & $\begin{array}{l}1.00 \times \\
10^{-3}\end{array}$ & N.A. & N.A. & $\begin{array}{l}4.02 \times \\
10^{-4}\end{array}$ \\
\hline Void formers & N.A. & N.A. & $\begin{array}{c}9.44 \times \\
10^{-8}\end{array}$ & N.A. & N.A. & $\begin{array}{c}9.44 \times \\
10^{-8}\end{array}$ & N.A. & N.A. & $\begin{array}{c}4.34 \times \\
10^{-2}\end{array}$ \\
\hline
\end{tabular}

The environmental impact of ready-mixed concrete is the highest factor for all of the environmental impact indicators in the three slab systems. While rebars were the lowest environmental impact element in the case of the OSS and the FPS, void formers were the smallest impact factor of all environmental indicators in the VDS. In this study, the VDS indicates less environmental impact from building materials, even though it would require additional building materials for construction. Differences in environmental impacts between the OSS and the FPS were relatively small, since a significant amount of building materials would be required for drop panels, which prevent punching shear in the FPS. In addition, the environmental impacts from the building materials for the VDS were considerably reduced, because the self-weight of the slab was lowered, and the number of beams and girders decreased.

\subsection{Discussion}

This study provides a significant contribution towards reducing the environmental impact of different slab systems by adopting the qualitative assessment method. In this study, the stage of manufacturing of building materials significantly impacts the environmental impact during the construction of slab systems. In particular, ready-mixed concrete is one of the main contributors to environmental impact. Reducing the environmental impact for the construction of slab systems requires the design of structural materials that balance the environmental impact and structural stability. Several studies have maintained that applying by-products and high-strength building materials would 
be one of the useful methods to reduce the environmental impact from concrete. In further research, a comparison of the normal and by-products added to ready-mixed concrete, as well as application of high-strength concrete and rebars should be carried out to enhance the reduction in environmental impacts during the manufacture of building materials.

In this study, the transportation of building materials is the second largest environmental impact source for all three slab systems. Mitigation of the environmental impacts from transportation requires selection of the proximate manufactures to the construction site, in order to reduce the fuel consumption during the procurement management process. Furthermore, it is necessary to minimise the lead time during the transportation of building materials to minimise the environmental impacts caused by fuel consumption. A number of studies have claimed that imported building materials would be beneficial to the economic perspective of building projects. However, imported materials would have a negative impact on the environment, since the transportation distance would be increased, as well as the use of additional transportation methods. Further research should be conducted to verify the relation between the environmental performance and economic effectiveness.

This study was carried out only for the construction of different slab systems and did not address the environmental impacts from various types of building, as well as entire construction projects. In order to fill such research gaps, further research that considers various types of buildings, such as commercial buildings and apartments, as well as the entire life cycle of buildings, should be carried out. Moreover, the numbers of examples in this study that were chosen were only one case for each slab system. In order to verify the environmental performance and sustainability of the voided slab systems against the ordinary reinforced concrete slab or flat plate slab, the number of samples for each slab system should be increased in future studies to enhance the results of this study.

\section{Conclusions}

The purpose of this study was to assess the various environmental impacts from the construction stage of the ordinary solid slab (OSS), the flat plate slab (FPS) and the voided slab system (VDS). The assessed environmental impact indicators were the Global Warming Potential (GWP), Acidification Potential (AP), Eutrophication Potential (EP), Ozone Layer Depletion Potential (ODP), Photochemical Ozone Creation Potential (POCP), and Abiotic Depletion Potential (ADP). In this study, the construction phase was confined to the manufacture of building materials, transportation of the building materials to the construction site, and the utilisation of construction equipment. A process-based quantitative model was adopted to calculate the six environmental impact indicators, and the comparative results were analysed to demonstrate the significant characteristics of the environmental impacts at the construction of slab in an apartment building in South Korea. The quantitative environmental assessment results during the construction phase of slab systems would provide a significant contribution to the reduction in environmental impacts. The conclusions of this study may be summarised as follows:

(1) In this study, the construction phase was divided into the manufacture of building materials, transportation of the building materials, and usage of construction machinery. The total environmental impacts from all the environmental indicators were the highest in the manufacture of building materials, followed by the transportation of building materials, and the use of construction machinery.

(2) The assessment results show that among the three slab systems, the environmental impacts from the OSS are the highest, while those of the VDS are the lowest. Along with the assessment of total environmental impacts, the variation of the environmental impacts by replacing the OSS with the FPS and the VDS was examined.

(3) As the slab system of the studied building was replaced, the environmental impact indicators showed a decreasing tendency.

(4) Replacing the OSS with the VDS showed the highest reduction ratio for all of the environmental impact indicators. This study also considered the environmental impact assessment results from each building material for the three different slab systems. 
(5) Based on the results of the environmental impact reductions from the three slab systems, the VDS would show the least environmental impact in all indicators.

The assessment results of this study should be used to conduct further research regarding the comparison of the environmental impacts of the whole life stage of a building, including construction, operation and maintenance, and demolition. Moreover, only major building materials for the construction of slab systems were dealt with in this study. Further research that takes into account all of the building materials would be useful to assess and compare the potential benefits from selecting among the alternative slab systems.

Author Contributions: I.P. designed the research method and calculated the quantities of building materials. S.N. conducted the structural analysis and the life cycle assessment from three slab systems in this research. All authors have read and agreed to the published version of the manuscript.

Funding: This research was funded by the National Research Foundation of Korea (NRF) grant number NRF-2019R1A6A3A01091459.

Acknowledgments: This work was supported by the National Research Foundation of Korea (NRF) grant funded by the Korea government Ministry of Education (No. NRF-2019R1A6A3A01091459).

Conflicts of Interest: We declare that there are no conflicts of interests between the authors of this research.

\section{References}

1. Roh, S.; Tae, S.; Suk, S.J.; Ford, G. Evaluating the embodied environmental impacts of major building tasks and materials of apartment buildings in Korea. Renew. Sust. Energy Rev. 2017, 73, 135-144. [CrossRef]

2. Gorobets, A. Eco-centric policy for sustainable development. J. Clean. Prod. 2014, 64, 654-655. [CrossRef]

3. Paik, I.; Na, S. Evaluation of Carbon Dioxide Emissions amongst Alternative Slab Systems during the Construction Phase in a Building Project. Appl. Sci. 2019, 9, 4333. [CrossRef]

4. Asdrubali, F.; Baldassarri, C.; Fthenakis, V. Life cycle analysis in the construction sector: Guiding the optimization of conventional Italian buildings. Energy Build. 2013, 64, 73-89. [CrossRef]

5. Sandanayake, M.; Zhang, G.; Setunge, S. Environmental emissions at foundation construction stage of buildings-Two case studies. Build. Environ. 2016, 95, 189-198. [CrossRef]

6. Guggemos, A.A.; Horvath, A. Comparison of Environmental Effects of Steel- and Concrete-Framed Buildings. J. Infrastruct. Syst. 2005, 11, 93-101. [CrossRef]

7. Sartori, I.; Hestnes, A. Energy use in the life cycle of conventional and low-energy buildings: A review article. Energy Build. 2007, 39, 249-257. [CrossRef]

8. Basbagill, J.; Flager, F.; Lepech, M.; Fischer, M. Application of life-cycle assessment to early stage building design for reduced embodied environmental impacts. Build. Environ. 2013, 60, 81-92. [CrossRef]

9. Na, S.; Paik, I. Reducing Greenhouse Gas Emissions and Costs with the Alternative Structural System for Slab: A Comparative Analysis of South Korea Cases. Sustainability 2019, 11, 5238. [CrossRef]

10. Kumar, V.; Hewage, K.; Sadiq, R. Life cycle assessment of residential buildings: A case study in Canada. Int. J. Energy Environ. Eng. 2015, 9, 1017-1025.

11. Mao, C.; Shen, Q.; Shen, L.; Tang, L. Comparative study of greenhouse gas emissions between off-site prefabrication and conventional construction methods: Two case studies of residential projects. Energy Build. 2013, 66, 165-176. [CrossRef]

12. Cabeza, L.F.; Barreneche, C.; Miró, L.; Morera, J.M.; Bartolí, E.; Fernández, A.I. Low carbon and low embodied energy materials in buildings: A review. Renew. Sust. Energy Rev. 2013, 23, 536-542. [CrossRef]

13. Sentman, S.D.; Del Percio, S.T.; Koerner, P. A Climate for Change: Green Building Policies, Programs, and Incentives. J. Green Build. 2008, 3, 46-63. [CrossRef]

14. Hong, J.; Shen, G.Q.; Feng, Y.; Lau, W.S.-T.; Mao, C. Greenhouse gas emissions during the construction phase of a building: A case study in China. J. Clean. Prod. 2015, 103, 249-259. [CrossRef]

15. Pacca, S.; Horvath, A. Greenhouse Gas Emissions from Building and Operating Electric Power Plants in the Upper Colorado River Basin. Environ. Sci. Technol. 2002, 36, 3194-3200. [CrossRef]

16. Wang, T.; Seo, S.; Liao, P.-C.; Fang, D. GHG emission reduction performance of state-of-the-art green buildings: Review of two case studies. Renew. Sust. Energy Rev. 2016, 56, 484-493. [CrossRef] 
17. Hong, T.; Koo, C.; Kim, J.; Lee, M.; Jeong, K. A review on sustainable construction management strategies for monitoring, diagnosing, and retrofitting the building's dynamic energy performance: Focused on the operation and maintenance phase. Appl. Energy 2015, 155, 671-707. [CrossRef]

18. Mlecnik, E. Defining nearly zero-energy housing in Belgium and the Netherlands. Energy Effic. 2011, 5, 411-431. [CrossRef]

19. Moore, T.; Morrissey, J. Lifecycle costing sensitivities for zero energy housing in Melbourne, Australia. Energy Build. 2014, 79, 1-11. [CrossRef]

20. Ferrante, A.; Cascella, M. Zero energy balance and zero on-site CO2 emission housing development in the Mediterranean climate. Energy Build. 2011, 43, 2002-2010. [CrossRef]

21. Edwards, R.E.; New, J.; Parker, L.E. Predicting future hourly residential electrical consumption: A machine learning case study. Energy Build. 2012, 49, 591-603. [CrossRef]

22. Oh, M.-S.; Na, S. Building Information Modelling (BIM) based CO2 emissions assessment in the early design stage. Int. J. Civ. Eng. Technol. 2017, 8, 1411-1425.

23. Ren, Z.; Foliente, G.; Chan, W.-Y.; Chen, D.; Ambrose, M.; Paevere, P. A model for predicting household end-use energy consumption and greenhouse gas emissions in Australia. Int. J. Sust. Build. Technol. Urban. Dev. 2013, 4, 210-228. [CrossRef]

24. Yan, H.; Shen, Q.; Fan, L.C.; Wang, Y.; Zhang, L. Greenhouse gas emissions in building construction: A case study of One Peking in Hong Kong. Build. Environ. 2010, 45, 949-955. [CrossRef]

25. González, M.J.; Navarro, J.G. Assessment of the decrease of $\mathrm{CO} 2$ emissions in the construction field through the selection of materials: Practical case study of three houses of low environmental impact. Build. Environ. 2006, 41, 902-909. [CrossRef]

26. Pacheco-Torres, R.; Jadraque, E.; Roldán-Fontana, J.; Ordóñez, J. Analysis of CO2 emissions in the construction phase of single-family detached houses. Sust. Cities Soc. 2014, 12, 63-68. [CrossRef]

27. Cho, S.-H.; Chae, C.-U. The Comparative Study on the Environmental Impact Assessment of Construction Material through the Application of Carbon Reducing Element-Focused on Global Warming Potential of Concrete Products. KIEAE J. 2015, 15, 147-154. [CrossRef]

28. Goverse, T.; Hekkert, M.P.; Groenewegen, P.; Worrell, E.; Smits, R.E. Wood innovation in the residential construction sector; opportunities and constraints. Res. Conserv. Recycl. 2001, 34, 53-74. [CrossRef]

29. Tae, S.; Baek, C.; Shin, S. Life cycle CO2 evaluation on reinforced concrete structures with high-strength concrete. Environ. Impact Assess. Rev. 2011, 31, 253-260. [CrossRef]

30. Park, H.S.; Kwon, B.; Shin, Y.; Kim, Y.; Hong, T.; Choi, S.W. Cost and CO2 Emission Optimization of Steel Reinforced Concrete Columns in High-Rise Buildings. Energies 2013, 6, 5609-5624. [CrossRef]

31. Cho, S.; Na, S. The Reduction of CO2 Emissions by Application of High-Strength Reinforcing Bars to Three Different Structural Systems in South Korea. Sustainability 2017, 9, 1652. [CrossRef]

32. Naik, T.R.; Moriconi, G. Environmental-friendly durable concrete made with recycled materials for sustainable concrete construction. In Proceedings of the International Symposium on Sustainable Development of Cement, Concrete and Concrete Structures, Toronto, ON, Canada, 5 October 2005.

33. Coelho, A.; De Brito, J. Environmental analysis of a construction and demolition waste recycling plant in Portugal-Part I: Energy consumption and CO2 emissions. Waste Manag. 2013, 33, 1258-1267. [CrossRef]

34. Garg, C.; Jain, A. Green concrete: Efficient \& eco-friendly construction materials. Impact J. 2014, 2, $259-264$.

35. Kim, T.-H.; Chae, C.-U.; Kim, G.H.; Jang, H.J. Analysis of CO2 Emission Characteristics of Concrete Used at Construction Sites. Sustainability 2016, 8, 348. [CrossRef]

36. Broms, C.E. Elimination of flat plate punching failure mode. ACI Struct. J. 2000, 97, 94-101.

37. Bae, B.-I.; Chung, J.-H.; Choi, H.-K.; Jung, H.-S.; Choi, C.-S. Experimental study on the cyclic behavior of steel fiber reinforced high strength concrete columns and evaluation of shear strength. Eng. Struct. 2018, 157, 250-267. [CrossRef]

38. Choi, H.-K. Experimental Study on Shear Wall with Slab and Openings. Int. J. Civ. Eng. 2016, 15, 451-471. [CrossRef]

39. Mansour, F.R.; Abu Bakar, S.; Ibrahim, I.S.; Marsono, A.K.; Marabi, B. Flexural performance of a precast concrete slab with steel fiber concrete topping. Constr. Build. Mater. 2015, 75, 112-120. [CrossRef]

40. Cao, X.; Li, X.; Zhu, Y.; Zhang, Z. A comparative study of environmental performance between prefabricated and traditional residential buildings in China. J. Clean. Prod. 2015, 109, 131-143. [CrossRef]

41. Miller, D.; Doh, J.-H.; Mulvey, M. Concrete slab comparison and embodied energy optimisation for alternate design and construction techniques. Constr. Build. Mater. 2015, 80, 329-338. [CrossRef] 
42. Ferreiro-Cabello, J.; Fraile-Garcia, E.; Ascacibar, E.M.D.P.; Ascacibar, F.J.M.D.P. Minimizing greenhouse gas emissions and costs for structures with flat slabs. J. Clean. Prod. 2016, 137, 922-930. [CrossRef]

43. International Organization for Standardization. ISO:14040: Environmental Management Life Cycle Assessment Principles and Framework; ISO: Geneva, Switzeland, 2006.

44. Bilec, M.; Ries, R.; Matthews, H.S.; Sharrard, A.L. Example of a Hybrid Life-Cycle Assessment of Construction Processes. J. Infrastruct. Syst. 2006, 12, 207-215. [CrossRef]

45. Suzuki, M.; Oka, T. Estimation of life cycle energy consumption and CO2 emission of office buildings in Japan. Energy Build. 1998, 28, 33-41. [CrossRef]

46. Treloar, G.J.; Love, P.E.D.; Faniran, O.O.; Iyer-Raniga, U. A hybrid life cycle assessment method for construction. Constr. Manag. Econ. 2000, 18, 5-9. [CrossRef]

47. Chen, T.; Burnett, J.; Chau, C. Analysis of embodied energy use in the residential building of Hong Kong. Energy 2001, 26, 323-340. [CrossRef]

48. International Organization for Standardization. ISO14044: Life Cycle Assessment (Requirement and Guidelines); International Organization for Standardization: Geneva, Switzeland, 2006.

49. International Organization for Standardization (ISO). ISO:21930: Environmental Declaration of Building Product; ISO: Geneva, Switzeland, 2007.

50. Nässén, J.; Holmberg, J.; Wadeskog, A.; Nyman, M. Direct and indirect energy use and carbon emissions in the production phase of buildings: An input-output analysis. Energy 2007, 32, 1593-1602. [CrossRef]

51. Sharrard, A.L. Greening Construction Processes Using an Input output-Based Hybrid Life Cycle Assessment Model; Department of Civil and Environmental Engineering, Carnegie Mellon University: Pittsburgh, PA, USA, 2007.

52. Onat, N.C.; Kucukvar, M.; Tatari, O. Scope-based carbon footprint analysis of U.S. residential and commercial buildings: An input-output hybrid life cycle assessment approach. Build. Environ. 2014, 72, 53-62. [CrossRef]

53. Korea Environmental Industry and Technology Institute. Korea LCI DB Information Network. 2017. Available online: http://www.epd.or.kr/en/lci/lci_intro.asp (accessed on 21 June 2020).

54. Federal Ministry of the Interior. B.a.C. Ökobaudat Sustainabil Construction Information Portal. Available online: https://www.oekobaudat.de/en.html (accessed on 20 June 2020).

55. Korea Concrete Institute. Structural Concrete Design Code and Commentary; Korea Institute of Concrete: Seoul, Korea, 2012.

56. American Concrete Institute (ACI). Building Code Requirements for Structural Concrete (ACI 319-05) and Commentary (ACI 318R-05); American Institute of Concrete: Farmington Hills, MI, USA, 2008.

57. Hong, E.-A.; Chung, L.; Paik, I.; Yun, S.-H.; Cho, S.-H. Structural Performance and Usability of Void Slab Established in T-deck Plate. J. Korea Concr. Inst. 2012, 24, 677-684. [CrossRef]

Publisher's Note: MDPI stays neutral with regard to jurisdictional claims in published maps and institutional affiliations.

(C) 2020 by the authors. Licensee MDPI, Basel, Switzerland. This article is an open access article distributed under the terms and conditions of the Creative Commons Attribution (CC BY) license (http://creativecommons.org/licenses/by/4.0/). 